\title{
DAMPAK PEMBINAAN REFLEKTIF TERHADAP PENGEMBANGAN PROFESIONALISME DAN KETERAMPILAN MENGAJAR GURU
}

\author{
Daman Rasman Syarif Hidayat \\ Universitas Indraprasta PGRI Jakarta, Indonesia \\ Email: daman@unindra.ac.id
}

\begin{abstract}
Abstrak
Pembinaan reflektif sebagai model formatif terutama bertujuan untuk mengevaluasi dan membantu guru mengembangkan keterampilan mengajar. Untuk memahami konteks pembinaan reflektif, seseorang perlu memahami makna refleksi. Metode yang digunakan dalam penelitian ini adalah metode kualitatif dengan pendekatan pra-eksperimental. Penelitian ini dilakukan selama semester pertama Tahun Pelajaran 2018-2019. Diikuti 30 guru SMA Al-Ihsan Jakarta. Terdiri dari 16 guru perempuan dan 14 guru laki-laki dengan usia berkisar antara 22 hingga 40 tahun. Studi dilakukan selama pelatihan program pendidikan guru. Dari penelitian ini, dapat diketahui bahwa Pembinaan reflektif, dalam konteks ini, dianggap memainkan peran penting dalam menciptakan upaya yang mengutamakan kolaborasi. Ini juga merupakan model pengawasan yang layak dan berpotensi dapat digunakan kembali baik dalam konteks pra-layanan dan dalam-layanan.
\end{abstract}

Kata Kunci: Pembinaan Reflektif, Pengembangan, Profesional, Keterampilan.

\begin{abstract}
Reflective coaching as a formative model mainly aims to evaluate and help teachers develop teaching skills. To understand the context of reflective coaching, one needs to understand the meaning of reflection. The method used in this study is a qualitative method with a preexperimental approach. This research was conducted during the first semester of the 20182019 Academic Year. 30 teachers from Al-Ihsan High School Jakarta were joined. It consists of 16 female teachers and 14 male teachers with ages ranging from 22 to 40 years. The study was conducted during the teacher education program training. From this research, it can be seen that reflective coaching, in this context, is considered to play an important role in creating efforts that prioritize collaboration. It is also a viable and potentially reusable monitoring model in both pre-service and in-service contexts.
\end{abstract}

Keywords: Reflective Coaching, Development, Professional, Skills.

\section{A. PENDAHULUAN}

Pembinaan reflektif dengan jelas menunjukkan bahwa yang pertama, tindakan refleksi adalah ketika seorang praktisi yang berpengalaman dalam mengajar, berusaha untuk berpikir sendiri dan dapat mengatasi masalah serta menerima informasi baru (Amir, 2013). Namun, praktisi/pendidik perlu terlibat dalam analisis lebih lanjut untuk pemahaman yang lebih baik tentang peran siswa dan guru dalam konteks pembelajaran (Fitria, Kristiawan \& Rahmat, 2019). Mengintegrasikan pengalaman dengan teori dengan mengungkapkan kemungkinan baru untuk melihat kelemahan dan perubahan, refleksi dianggap untuk mengimprovisasi pikiran, perasaan, dan tindakan seseorang (Gunawan, Alifiyah \& Evananda, 2017). 
Istilah pendidik (dan bentuk-bentuk terkait, seperti pembinaan) telah menjadi begitu luas sehingga melemahkan kemampuannya untuk mengomunikasikan ide atau praktik tertentu (Indrawan, Arnyana \& Pujani, 2014). Istilah ini menjadi kurang bermakna karena stereotip yang buruk dan mungkin tidak adil dalam bidang pembinaan murid, dan dalam berbagai konteks organisasi dalam institusi pendidikan (Hasanudin, 2021). Namun, dalam konteks pendidikan SMA, konsep pembinaan di dunia akademis (jangan disamakan dengan pembinaan akademik) mulai terbentuk sedemikian rupa untuk membentuk stereotip baik dan berfungsi sebagai metafora, model, dan seperangkat praktik yang memajukan bidang yang saling terkait dari pengembangan profesional, fakultas, dan organisasi (Hasanudin \& Awaloedin, 2020).

Pengembangan pembinaan pendidik berfokus pada hal yang menjembatani kesenjangan antara apa yang terjadi di kelas dan temuan dari badan penelitian yang semakin dinamis yang mengungkap wawasan dan praktik baru mengenai pembelajaran siswa (Marlina, 2016). Bidang tersebut mencerminkan penekanannya pada instruktur dan perkembangan peserta didik (Masruroh, 2010). Namun, seiring dengan munculnya bidang tersebut melalui tahap-tahap berurutan yang telah meningkatkan cakupan, dampak, dan signifikansi pekerjaan yang dilakukan oleh pusat-pusat pengajaran serta pembelajaran (Nugrawati, 2010).

Perluasan bidang ini terjadi di dua hal yang saling melengkapi, pertama, karena ruang lingkup pekerjaan meningkat untuk memasukkan peran guru di luar pengajaran dan pembelajaran, dan kedua, karena skala pekerjaan meningkat untuk memasukkan dampak yang lebih luas dari pendidik baik di luar atau di ruang kelas (Nurwulandari \& Adnyana, 2019).

Dalam praktik reflektif, para pemimpin institusi sering membangkitkan metafora untuk menyampaikan gaya khas seorang pemimpin, seperti contoh di bawah ini, di mana Nelson Mandela (sebagai pemimpin) memberikan sebuah nasihat kepada para pendidik: Dalam beberapa hal, saya melihat taman sebagai metafora untuk aspek-aspek tertentu dalam hidup saya. Seorang pemimpin juga harus merawat kebunnya; dia juga harus menjahit benih, dan kemudian mengawasi, mengolah dan memanen hasilnya. Seperti tukang kebun, seorang pemimpin harus bertanggung jawab atas apa yang dia tanam; dia harus memikirkan pekerjaannya, mencoba mengusir musuh, melestarikan apa yang bisa dipertahankan dan menghilangkan apa yang tidak bisa berhasil.

Sangat penting bagi guru untuk mengembangkan diri peserta secara profesional, meningkatkan pengetahuan teoretis, praktik, dan keterampilan teknologi, karena elemenelemen ini memainkan peran penting dalam kualitas pengajaran sepanjang karir profesional pendidik (Nurwulandari, Hasanudin \& Melati, 2021). Dengan demikian, penekanan reguler telah diberikan untuk perubahan dan pengembangan sifat profesi guru (Qolbi, 2016). Sedangkan untuk pengajaran, pengembangan profesional didefinisikan sebagai salah satu dari banyak proses yang menyediakan lingkungan belajar dan mengajar yang efektif dengan meningkatkan pengetahuan, keterampilan, nilai, dan sikap guru (Sianturi, 2014). Sejumlah besar penelitian telah menyimpulkan bahwa kualitas pengajaran dan dengan demikian keberhasilan siswa dapat ditingkatkan dengan menyempurnakan pengembangan profesional guru (Slameto, 2014). 
Karena kebutuhan akan perubahan dan peningkatan profesi guru menyangkut semua bidang dalam pendidikan dan ilmu pendidikan, maka pengembangan profesional merupakan hal yang vital bagi guru yang bekerja di bidang pendidikan luar biasa (Tambak \& Sukenti, 2020). Alasan mengapa guru pendidikan luar biasa harus mengembangkan diri secara profesional adalah kebutuhan anak usia sekolah telah berubah secara positif karena perluasan diagnosis dini dan kesempatan pendidikan, kemajuan perangkat dan sistem teknologi, dan praktik pendidikan dan instruksional baru berdasarkan bukti (Wahyudi \& Pangestuti, 2017).

\section{B. METODE}

Pendekatan pra-eksperimental digunakan dalam penelitian ini menggunakan metode penelitian kualitatif. Karena, ini adalah jenis desain pra-eksperimental, di mana satu kelompok unit uji diberi perlakuan eksperimental dan hanya mengukur hasil post-test tanpa menggunakan kelompok kontrol (Zulfa, 2017).

Penelitian ini dilakukan selama semester pertama Tahun Pelajaran 2018-2019. Diikuti 30 guru SMA Al-Ihsan Jakarta. Terdiri dari 16 guru perempuan dan 14 guru laki-laki dengan usia berkisar antara 22 hingga 40 tahun. Studi dilakukan selama pelatihan program pendidikan guru. Kursus Manajemen Kelas terutama berfokus pada pengamatan kelas sebagai bagian dari pengajaran mikro dan kemudian pengajaran pelajaran penuh, menempatkan pedagogi ke dalam praktik bersama dengan evaluasi. Kesadaran akan kelemahan dan kekuatan peserta pelatihan saat mempersiapkan praktik mengajar merupakan fokus utama dalam jenis praktik reflektif ini.

Pelatihan pembinaan reflektif juga mencakup: 1) Diskusi dan analisis video tentang kursus sampel yang direkam sebelumnya, 2) Pembelajaran Jurnal Pedagogik terkait, dan 3) Prosedur pemberian umpan balik berdasarkan prinsip-prinsip pengajaran reflektif selama sesi pembinaan reflektif.

\section{HASIL DAN PEMBAHASAN}

SPSS (Statistical Package for the Social Sciens) menggunakan uji-t dan frekuensi digunakan untuk menganalisis data. Selain itu, daftar periksa evaluasi yang disiapkan oleh peneliti untuk menilai pengajaran guru digunakan untuk melihat efek perlakuan pada setiap pengembangan keterampilan mengajar, level kualitas, dan kinerja yang lengkap (yaitu, sejauh mana ada bukti dari semua keterampilan mengajar di kelas). Selain itu, banyak poin diskusi, wawancara, anekdot, tanggapan yang berfokus pada keterampilan mengajar, materi, tugas, metode pengajaran yang direkam selama sesi konferensi reflektif juga dianalisis dan beberapa contoh dialog yang menggambarkan peneliti (sebagai pelatih reflektif), dan mengajar interaksi perwakilan selama sesi konferensi reflektif dimasukkan dalam bagian temuan.

Kuesioner terbuka sebagai instrumen lain termasuk pertanyaan, yang dibangun berdasarkan Pedoman Pertanyaan Refleksi. Validitas dan reliabilitas instrumen ini ditetapkan oleh pengembang. Kemudian peserta diminta untuk memperoleh informasi yang diperlukan tentang pemahaman peserta tentang praktik reflektif. Peserta memperoleh dan menyetujui 20 pertanyaan terbuka. Menurut peserta, jawaban atas pertanyaan-pertanyaan yang dipilih, akan membantu peserta melakukan pengajaran yang lebih efisien dan mandiri dan ini akan mencerminkan keyakinan mengendalikan tuntutan pengembangan profesional melalui 
tindakan improvisasi.

Tiga penilai, berpengalaman dalam pendidikan guru, bekerja dengan para peserta, dan peserta dilatih tentang cara menginterpretasikan data yang direkam. Selama empat sesi orientasi 2 jam, diskusi dilakukan tentang implikasi keterampilan mengajar yang disorot. Untuk menunjukkan bagaimana menilai dan membandingkan, sampel kaset video digunakan. Setelah sesi orientasi untuk setiap kelompok, penilai mengukur tiga kaset video pelajaran calon guru lagi secara mandiri. Konsistensi internal menghasilkan 0,87 untuk kualitas penggunaan dan 0,91 untuk frekuensi kemunculan menggunakan alpha Cronbach.

Sebanyak 20 kaset video (5 dari pra-penilaian dan 15 dari pasca-penilaian) dinilai sesuai dengan prosedur secara independen setelah pelatihan; setiap penilai mengevaluasi setiap kaset dan saat memberi peringkat, satu kaset video dipilih secara acak untuk menjaga keandalan antar penilai. Pemilihan ini menghasilkan kesepakatan antar penilai sebesar 92\% untuk demonstrasi keseluruhan, $85 \%$ untuk kualitas penggunaan, dan $87 \%$ untuk frekuensi kemunculan.

\section{Pertanyaan Penelitian Satu}

Sarana dan standar deviasi untuk kinerja mengajar secara keseluruhan untuk pra dan pasca penerapan daftar periksa evaluasi ditampilkan pada Tabel 1. Menurut temuan, seperti dapat dilihat pada Tabel 1 , ada perbedaan yang signifikan antara nilai rata-rata $(t=12,343$, $\mathrm{df}=29$, signifikan pada $=0,02$ ). Pada pra-tahap daftar periksa evaluasi, skor rata-rata oleh siswa guru pada kinerja mengajar secara keseluruhan adalah $(8,977)$ dibandingkan dengan setelah aplikasi $(13,982)$.

Hasil ini jelas mendukung daftar periksa evaluasi pasca-aplikasi. Selanjutnya, nilai estimasi efek ukuran adalah 7,08, yang dengan jelas menunjukkan bahwa ukuran efek dari program pelatihan telah cukup efektif dalam meningkatkan kinerja mengajar guru siswa. Jadi, dapat disimpulkan bahwa orientasi pembinaan reflektif terbukti efektif dalam meningkatkan kinerja mengajar guru secara keseluruhan untuk keterampilan yang ditargetkan.

Tabel 1. Hasil Uji-T untuk Membandingkan Kinerja Mengajar Guru

\begin{tabular}{|c|c|c|c|c|c|c|c|c|}
\hline Measure & Mean & S.D & $\begin{array}{c}\text { Mean } \\
\text { Difference }\end{array}$ & S.D & D.F. & $\boldsymbol{T}$ & Sig & $\begin{array}{c}\text { Effect } \\
\text { Size }\end{array}$ \\
\hline Pre & 8.977 & 2.008 & 2.886 & 0.967 & 29 & 12.343 & 0.02 & 7.08 \\
\hline Post & 13.982 & 0.698 & & & & & & \\
\hline
\end{tabular}

Sumber: Data diolah

\section{Pertanyaan Penelitian Kedua}

Sarana dan standar deviasi untuk setiap keterampilan yang ditargetkan pada pra/pasca penerapan daftar periksa evaluasi ditunjukkan pada Tabel 2. 
ARTIKEL

Tabel 2 Hasil uji-T untuk Membandingkan Kinerja Mengajar Siswa Guru Secara Keseluruhan dalam Keterampilan Yang Ditargetkan

\begin{tabular}{|c|c|c|c|c|c|c|c|c|c|}
\hline Skills & Measure & Mean & S.D. & $\begin{array}{c}\text { Mean } \\
\text { Difference }\end{array}$ & S.D. & D.F & $T$ & Sig & Effect \\
\hline $\begin{array}{l}\text { Perencanaan } \\
\text { Pengajaran }\end{array}$ & $\begin{array}{l}\text { Pre } \\
\text { Post }\end{array}$ & $\begin{array}{l}5.898 \\
7.784\end{array}$ & $\begin{array}{c}0.797 \\
0.3221\end{array}$ & 2.103 & 0.799 & 29 & 12.5 & 0.02 & 4.97 \\
\hline $\begin{array}{l}\text { Pengantar } \\
\text { Pembelajaran }\end{array}$ & $\begin{array}{l}\text { Pre } \\
\text { Post }\end{array}$ & $\begin{array}{c}7.5227 \\
13.4899\end{array}$ & $\begin{array}{l}1.89224 \\
0.79885\end{array}$ & 6.2976 & 1.1788 & 29 & 12.979 & 0.02 & 5.97 \\
\hline $\begin{array}{l}\text { Praktik } \\
\text { Mengajar } \\
\text { Materi Baru }\end{array}$ & $\begin{array}{l}\text { Pre } \\
\text { Post }\end{array}$ & $\begin{array}{l}14.8986 \\
17.9796\end{array}$ & $\begin{array}{l}1.9974 \\
1.2324\end{array}$ & 2.8976 & 0.8496 & 29 & 9.897 & 0.02 & 4.24 \\
\hline $\begin{array}{l}\text { Menejemen } \\
\text { Kelas }\end{array}$ & $\begin{array}{l}\text { Pre } \\
\text { Post }\end{array}$ & $\begin{array}{c}7.8987 \\
13.4887 \\
\end{array}$ & $\begin{array}{l}1.2885 \\
.48024 \\
\end{array}$ & 3.814 & .6239 & 29 & 12.944 & 0.02 & 5.7 \\
\hline Evaluasi & $\begin{array}{l}\text { Pre } \\
\text { Post }\end{array}$ & $\begin{array}{l}7.1966 \\
9.2447 \\
\end{array}$ & $\begin{array}{c}.81 .325 \\
.3695 \\
\end{array}$ & 1.9615 & 1.6985 & 29 & 10.652 & 0.02 & 4.8 \\
\hline
\end{tabular}

Sumber: Data diolah

Seperti dapat dilihat pada tabel kedua, temuan uji-T menunjukkan perbedaan yang signifikan secara statistik yang mendukung evaluasi pasca-tahap. Untuk perencanaan pembelajaran, terlihat bahwa nilai t yang diestimasi adalah 12,5, dengan perbedaan yang signifikan pada level 0,02 yang mendukung kinerja guru siswa pada pasca-tahap. Di sisi lain, dengan estimasi nilai effect size sebesar 4,97, terlihat bahwa pelatihan reflektif coaching terbukti efektif dalam meningkatkan kinerja siswa guru dalam merencanakan pembelajaran. Selain itu, untuk bagian keterampilan pengantar pelajaran, terlihat bahwa nilai $\mathrm{t}$ yang diestimasi adalah $(12,979)$ dengan perbedaan yang signifikan pada tingkat 0,01 yang mendukung kinerja guru siswa. Selanjutnya, nilai estimasi effect size sebesar 5,97 menunjukkan bahwa orientasi pembinaan reflektif kembali terbukti efektif dalam meningkatkan kinerja siswa guru untuk memperkenalkan pelajaran.

Sejauh Praktik Mengajar Materi Baru, terlihat bahwa nilai perkiraan ukuran efek adalah 4,24, yang berarti bahwa orientasi pembinaan reflektif memiliki dampak yang tinggi pada praktik materi baru. Nilai t yang diperkirakan adalah 9,897, dengan perbedaan signifikan pada level 0,02 yang mendukung kinerja peserta pada aplikasi pasca-tahap. Mengenai keterampilan manajemen kelas, seperti yang ditunjukkan pada Tabel 2, nilai t yang diperkirakan adalah 12,944, yang sekali lagi menunjukkan perbedaan yang signifikan secara statistik pada 0,02 yang mendukung kinerja guru siswa pada tahap akhir daftar periksa.

Dengan demikian, seseorang dapat menyimpulkan bahwa pelatihan pembinaan reflektif tinggi dalam meningkatkan keterampilan manajemen kelas peserta dengan perkiraan nilai ukuran efek 5,6. Terakhir, untuk keterampilan evaluasi, terlihat pada Tabel 2 bahwa nilai t yang diestimasi adalah 10,642 yang memiliki perbedaan signifikan pada level 0,02 dan mendukung kinerja peserta pada pasca-tahap penerapan dengan nilai estimasi efek ukuran 4,8. Sebagai kesimpulan, pelatihan reflektif coaching yang dilaksanakan dalam penelitian ini telah berkontribusi pada peningkatan kemampuan peserta untuk mengevaluasi siswa peserta.

Meskipun tanggapan selama sesi konferensi reflektif terfokus pada keterampilan mengajar, pertimbangan lain untuk membahas tugas, metode pengajaran, materi dan siswa juga tersedia. 


\section{Pertanyaan Penelitian Tiga}

Pertanyaan ini mencoba mengungkap persepsi dan pemahaman guru tentang model pereflektif coaching. Persentase dan frekuensi diperoleh dari jawaban guru atas 26 pertanyaan dan jawaban dengan mempertimbangkan prinsip-prinsip pembinaan reflektif. Tanggapan terdiri dari 22 peserta dianalisis sebagai 8 tidak hadir saat kuesioner dibagikan. Kami juga menanyakan pendapat peserta tentang pelatihan reflektif coaching yang dilaksanakan. Jawaban yang diperoleh menunjukkan bahwa sebagian besar (84\%) merasa puas dengan pelatihan reflectife coaching dan memberikan komentar positif.

Lebih lanjut, $82 \%$ dari peserta menyatakan bahwa peserta merasa pelatihan sangat berguna dalam menciptakan kesadaran akan kelemahan dan kekuatan pengajaran, dan peserta menyatakan bahwa peserta mendapat kesempatan untuk mengidentifikasi masalah. Sementara itu, 74\% dari peserta menyatakan bahwa peserta memiliki kesempatan untuk mengembangkan pemahaman baru untuk menjadi guru yang kreatif dan bijaksana.

Di sisi lain, $72 \%$ dari peserta menyatakan bahwa peserta belajar bagaimana melakukan evaluasi objektif dan klinis untuk diri peserta sendiri dan orang lain untuk melihat kekuatan dan kelemahan peserta selama pelajaran. Lebih dari setengahnya (68\%) menyatakan bahwa peserta diperkenalkan dengan strategi yang efektif untuk memahami metode pemecahan masalah yang digunakan dalam praktik mengajar. Menurut $60 \%$ dari peserta, kemajuan dicapai dalam mewujudkan teori belajar. Namun, hampir $10 \%$ dari peserta menyatakan tidak ingin mengikuti pelatihan karena dianggap tidak akan berkontribusi pada pengembangan profesional pengajar.

\section{KESIMPULAN}

Hasil dari penelitian ini menawarkan para pendidik untuk mengembangkan keterampilan peserta: pengenalan, perencanaan pembelajaran, penggunaan materi baru, pengelolaan kelas, dan evaluasi setelah program pembinaan reflektif dibandingkan dengan kinerja peserta sebelum pelaksanaan program. Hasilnya juga mengungkapkan bahwa sebagian besar responden puas dengan kemajuan peserta melalui program pembinaan reflektif. Peserta menyatakan bahwa model ini membantu peserta mengidentifikasi kelemahan peserta dalam mengajar, karakteristik guru yang kreatif dan efektif. Hasil mencolok lainnya adalah bahwa peserta menciptakan pemahaman baru tentang bagaimana mengamati dan mengevaluasi praktik peserta sendiri, dan jenis pembinaan ini membantu peserta dalam tugas-tugas pemecahan masalah. Pembinaan reflektif, dalam konteks ini, dianggap memainkan peran penting dalam menciptakan upaya yang mengutamakan kolaborasi. Ini juga merupakan model pengawasan yang layak dan berpotensi dapat digunakan kembali baik dalam konteks pra-layanan dan dalam-layanan.

\section{DAFTAR PUSTAKA}

Amir, A. (2013). Pengembangan profesionalisme guru dalam pembelajaran melalui model lesson study. Logaritma: Jurnal Ilmu-ilmu Pendidikan dan Sains, 1(02).

Fitria, H., Kristiawan, M., \& Rahmat, N. (2019). Upaya Meningkatkan Kompetensi Guru Melalui Pelatihan Penelitian Tindakan Kelas. Abdimas Unwahas, 4(1). 
Gunawan, I., Alifiyah, I., \& Evananda, F. (2017, November). Kompetensi Guru Sekolah Dasar: Sebuah Analisis Reflektif dengan Teknik Supervisi Pengajaran Penilaian Diri Sendiri. In Prosiding Seminar Nasional Sinergitas Keluarga, Sekolah, dan Masyarakat dalam Penguatan Pendidikan Karakter. Fakultas Ilmu Pendidikan Universitas Negeri Malang, Malang (Vol. 16, pp. 249-258).

Hasanudin, H. (2021). The Effect of Inflation, Exchange, SBI Interest Rate and Dow Jones Index on JCI on IDX 2013-2018. Budapest International Research and Critics Institute (BIRCI-Journal): Humanities and Social Sciences, 4(2), 2063-2072.

Hasanudin, H., \& Awaloedin, D. T. (2020). Pengaruh Current Ratio, Debt To Equity Ratio Dan Net Profit Margin Terhadap Return Saham Pada Perusahaan Jasa Sub Sektor Telekomunikasi Yang Terdaftar di BEI Periode 2012-2018. Jurnal Rekayasa Informasi, 9(1), 6-19.

Indrawan, I. P. O., Arnyana, I. B. P., \& Pujani, N. M. (2014). Pengaruh Diklat Lesson Study terhadap Kompetensi Profesional Guru IPA dan Prestasi Belajar Siswa SMKN 2 Seririt. Jurnal Pendidikan dan Pembelajaran IPA Indonesia, 4(2).

Marlina, L. (2016). Kajian Sistem Pembinaan Profesional Guru IPA. Edufisika: Jurnal Pendidikan Fisika, 1(2), 25-32.

Masruroh, F. (2010). Dampak Sertifikasi Sebagai Program Peningkatan Profesionalisme Guru Terhadap Kesejahteraan Dan Kinerja Guru. Progresiva, 4(1), 162397.

Nugrawati, N. E. (2010). Pembinaan Kemampuan Profesional Guru Sekolah Dasar (Studi Kualitatif Tentang Pembinaan Kemampuan Profesional Guru Sekolah Dasar di Kecamatan Bekasi Selatan Kota Bekasi). Jurnal Administrasi Pendidikan, 12(2).

Nurwulandari, A., \& Adnyana, I. (2019). Did Inter-Regional Trade Agreements Bring Mutual Benefits? An Empirical Scheme of Indonesian Commodity Exports in AseanChina Free Trade Area. International Journal of Financial Research, 10(6), 241-249.

Nurwulandari, A., Hasanudin, H., \& Melati, M. (2021). Market Reactions on Corporate Actions in Growing and Nongrowing Energy Consuming Companies. International Journal of Energy Economics and Policy, 11(3), 290-295.

Qolbi, L. (2016). Manajemen Supervisi Akademik Pengawas dalam Meningkatkan Kompetensi Propesional Guru Pendidikan Agama Islam di Sekolah Menengah Pertama Negeri 2 Sumber. Eduvis: Jurnal Manajemen Pendidikan Islam, 1(1), 31-42.

Sianturi, C. L. (2014). Asesmen Kebutuhan Pengembangan Profesionalisme Guru SMK. Jurnal Pendidikan Humaniora, 1(1), 16-24.

Slameto, S. (2014). Permasalahan-Permasalahan Terkait dengan Profesi Guru SD. Scholaria: Jurnal Pendidikan dan Kebudayaan, 4(3), 1-12.

Tambak, S., \& Sukenti, D. (2020). Pengembangan Profesionalisme Guru Madrasah Dengan Penguatan Konsep khalifah. Hayula: Indonesian Journal of Multidisciplinary Islamic Studies, 4(1), 41-66.

Wahyudi, S., \& Pangestuti, I. R. D. (2017). Managing the Pension Fund to Improve Portfolio Performance: An Empirical Study on Employer Pension Funds in Indonesia.

Wahyudi, S., Hasanudin, H., \& Pangestutia, I. (2020). Asset allocation and strategies on investment portfolio performance: A study on the implementation of employee pension fund in Indonesia. Accounting, 6(5), 839-850.

Wahyudin, D. (2016). Manajemen Kurikulum dalam Pendidikan Profesi Guru (Studi Kasus di Universitas Pendidikan Indonesia). Jurnal Kependidikan: Penelitian Inovasi Pembelajaran, 46(2), 259-270.

Zulfa, L. A. (2017). Problematika Dalam Melakukan Tindakan Reflektif Untuk Peningkatan Kualitas Pembelajaran Bahasa Indonesia. Eduscope: Jurnal Pendidikan, Pembelajaran, dan Teknologi, 2(2), 120-129. 